\title{
Treatment of Craniodiaphyseal Dysplasia Presenting with Chiari Type-I
}

\section{Tratamento de displasia craniodiafisária com Chiari tipo I}

\author{
Rafet Özay ${ }^{1}$ Ebru Doğan Doruk ${ }^{1}$ Mehmet Serdar Balkan ${ }^{1} \quad$ Mehmet Fikret Ergüngör ${ }^{2}$
}

${ }^{1}$ Clinic of Neurosurgery, Diskapi Yildirim Beyazit Training and Research Hospital, Ankara, Turkey

${ }^{2}$ Department of Neurosurgery, Cumhuriyet University, Sivas, Turkey Arq Bras Neurocir 2016;35:228-233.

\begin{abstract}
Address for correspondence Mehmet Serdar Balkan, MD, Clinic of Neurosurgery, Diskapi Yildirim Beyazit Training and Research Hospital, Asagi Eglence Mah, Etlik Cad. No:100/3, Kecioren, 06010, Ankara, Turkey (e-mail: mserdarbalkan@hotmail.com).
\end{abstract}

\begin{abstract}
Keywords

- skull

- hyperostosis

- dysplasia

- syringomyelia

- craniectomy

- decompression
\end{abstract}

\section{Resumo}

Objective Chiari malformation type-I (CM-1) is described radiographically as a simple displacement of the cerebellar tonsils at least $5 \mathrm{~mm}$ below the foramen magnum (FM). If $\mathrm{CM}-1$ exists due to hyperostosis of the cranial bones, the authors were not able to determine a common consensus for the treatment of CM-1 and syringomyelia.

Methods A31-year-old-female presented to our hospital with bilateral facial paralysis, hypoesthesia and motor loss of the extremities. The patient had bilateral gag reflex loss, phonation disorder and dysarthric speaking. Sensory and motor deficits were available at the bilateral upper and lower extremities. The skeletal radiographs revealed extensive thickening and sclerosis of the calvarial and facial bones, moderate widening and sclerosis of the clavicles and ribs, and that the internal auditory canal (IAC) and the optic foramen (OF) were narrowed. CM-1 and syringomyelia secondary to the small posterior fossa were due to calvarial hyperostosis. The patient underwent posterior fossa decompression and duraplasty. In addition, a syringosubarachnoid shunt was placed at the level of C7-T1. The symptoms of lower cranial nerve palsy and motor loss were recovered, but the symptoms of the foraminal stenosis, such as visual and auditory losses and facial paralysis were not recovered in any way.

Conclusion We described in this case report CM-1 as a late complication of craniodiaphyseal dysplasia (CDD), and the difficulties in its treatment. In the treatment of these patients with $C D D$, posterior fossa decompression and syringosubarachnoid shunting are necessary, in spite of all the risks of these procedures.

Objetivo A malformação Chiari tipo-I (MC-1) é descrita radiograficamente como um simples deslocamento da tonsila cerebelar de pelo menos $5 \mathrm{~mm}$ abaixo do forame magno (FM). Se houve MC-1 em função da hiperostose dos ossos do crânio, os autores não foram capazes de determinar um consenso para o tratamento de MC-1 e siringomielia.

Métodos Paciente de 31 anos deu entrada com paralisia facial bilateral, hipoestesia e perda motora das extremidades. A paciente apresentou perda de reflexo de vômito received

September 29, 2015

accepted

December 1, 2015

published online

July 26, 2016
DOI http://dx.doi.org/

$10.1055 / \mathrm{s}-0036-1586155$. ISSN 0103-5355.
Copyright $\odot 2016$ by Thieme Publicações License terms Ltda, Rio de Janeiro, Brazil
(®) $\Theta \circledast$ 


\section{Palavras-chave \\ - crânio \\ - hiperosteose \\ - displasia \\ - siringomielia \\ - craniotomia \\ - descompressão}

bilateral, desordem fonética e disartria. Deficiência motora e sensorial foram identificadas em ambas as extremidades superiores e inferiores. Radiografias do esqueleto revelaram extensa espessamento e esclerose dos ossos calvários e faciais, ampliação moderada e esclerose das clavículas e costelas, além de estreitamento do canal auditivo interno (CAI) e do forame ótico (FO). A MC-1 e siringomielia secundária à pequena fossa posterior ocorreram devido à hiperosteose calvarial. A paciente foi submetida a descompressão da fossa posterior e duroplastia. Somado a isso, um shunt siringo-subaracnóideo foi colocado na altura da C7-T1. Os sintomas de paralisia do nervo craniano inferior e a perda motora foram recuperados, mas os sintomas de estenose do forame, como por exemplo perdas auditivas e visuais, ou paralisia facial, não foram recuperados em nenhum nível.

Conclusão descrevemos neste relato de caso a MC-1 como uma complicação posterior da displasia craniodiafisária (DCD), além das dificuldades em seu tratamento. No tratamento desta paciente com DCD, são necessários a descompressão da fossa posterior e o shunt siringo-subaracnóideo, apesar de todos os riscos neste procedimento.

\section{Introduction}

Chiari malformation type-I (CM-I) is described radiographically as a simple displacement of the cerebellar tonsils at least $5 \mathrm{~mm}$ below the foramen magnum (FM). A pathophysiological mechanism of CM-I has been a very interesting subject of discussion for the neurosurgeon authors. However, cranial constriction, the low volume of the cranial posterior fossa, such as skull base hypoplasia (Klippel-Feil Syndrome, platybasia, achondroplasia, craniosynostosis), spinal cord tethering, intracranial hypertension, such as hydrocephalus and intracranial mass lesions, intraspinal hypotension, such as cerebrospinal fluid leaks, prolonged lumboperitoneal shunting and miscellaneous conditions, such as Paget's disease and occipitoatlantoaxial joint instability or fusion were suggested as mechanisms responsible for CM-I. ${ }^{1-7}$ Chiari malformation type-I has quite different clinical presentations because it is caused by various etiological factors. However, the syringomyelia and its treatment options were reported as a result of the most common different conditions. As a result of past clinical experience, an algorithm was determined, which includes respectively: if the hydrocephalus exists, ventriculoperitoneal shunting; if there is no hydrocephalus, decompression of the posterior cranial fossa (PCF) and syringosubarachnoid or syringoperitoneal shunting should be undertaken. ${ }^{8-11}$ However, if CM-I exists due to hyperostosis of the cranial bones, the authors were not able to arrive at a consensus for the treatment of CM-I and syringomyelia. This case report describes CM-I as a late complication of craniodiaphyseal dysplasia (CDD),and describes the difficulties involved in the treatment of this disease.

\section{Case Report}

A 31-year-old-female presented to our hospital with bilateral facial paralysis, hypoesthesia and motor loss of the extremities (approximately; upper extremity; 4/5, lower extremity; 3/5). Her brother and sister had also suffered CDD. The patient had headache, visual and auditory losses, difficulty in walking, dysphagia, and complaints due to recurrent upper respiratory tract infections. The patient was born from parents who had a consanguineous marriage. The pregnancy and delivery were unremarkable, and no abnormalities were noted at birth. At the age of 26 , her complaints started, and the parents noted similar abnormal facial features on her brother and sister. Physical examination revealed a grossly deformed head; the jaw was prominent, and there was kyphoscoliosis of the dorsal spine. The bilateral nasolabial grooves were absent, and there was bilateral peripheral facial paralysis, and bilateral partial visual and hearing losses. The patient had bilateral gag reflex loss, phonation disorder and dysarthric speaking. Sensory and motor deficits were available at the bilateral upper and lower extremities. Sphincter function was intact. The biochemical parameters, such as serum calcium, serum phosphate, alkaline phosphatase, renal function tests and liver function tests were normal. The skeletal radiographs revealed extensive thickening and sclerosis of the calvarial and facial bones (-Fig. 1), moderate widening and sclerosis of the clavicles and ribs, and increased density of the neural arches of the vertebrae (-Fig. 2). The internal auditory canal (IAC) and the optic foramen (OF) were narrowed (-Fig. 1). The imaging findings revealed cervicomedullary compression as well. Chiari malformation type-I and syringomyelia secondary to the small posterior fossa were due to calvarial hyperostosis (-Fig. 3). The patient underwent posterior fossa decompression and duraplasty. The occipital bone, which was four times thicker than the normal level (approximately $4 \mathrm{~cm}$ in diameter), was drilled and removed (-Fig. 4). In addition, a syringosubarachnoid shunt was placed at the level of C7-T1. On her follow-up visit, the patient had recovery in her phonation, walking disturbance 


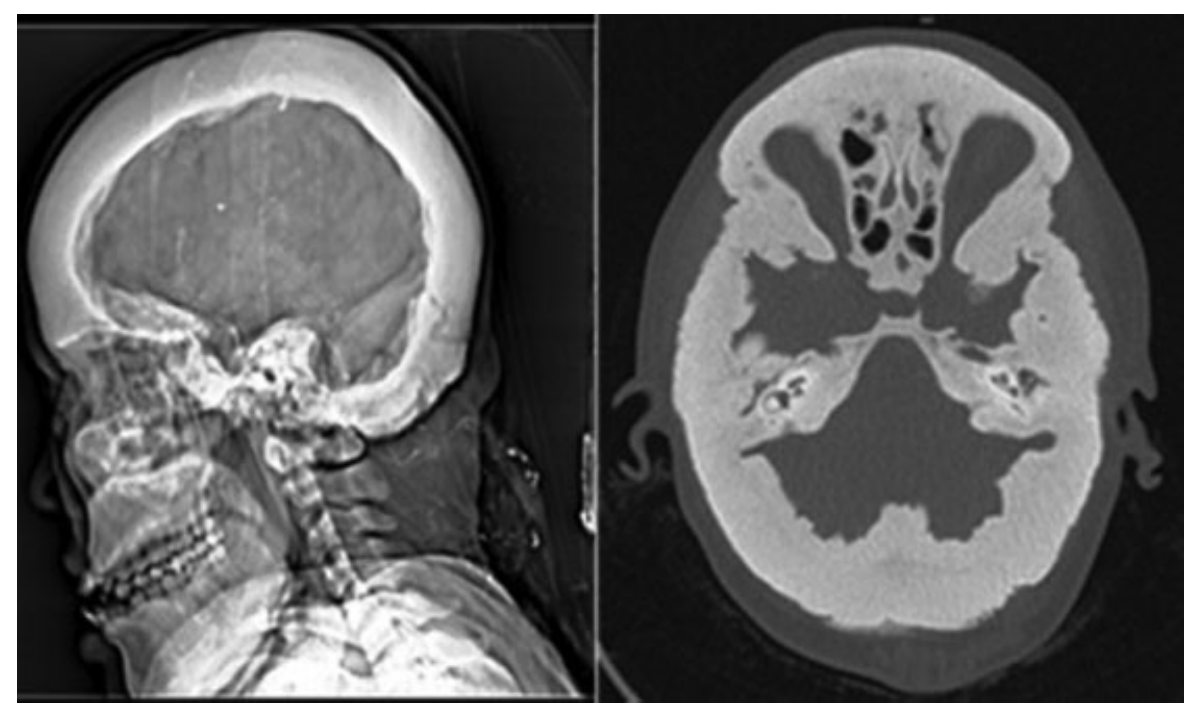

Fig. 1 Sagittal topogram and axial CT scan demonstrate a diffuse thickening of the calvarium and foraminal narrowing (such as IAC and OF) due to hyperostosis.

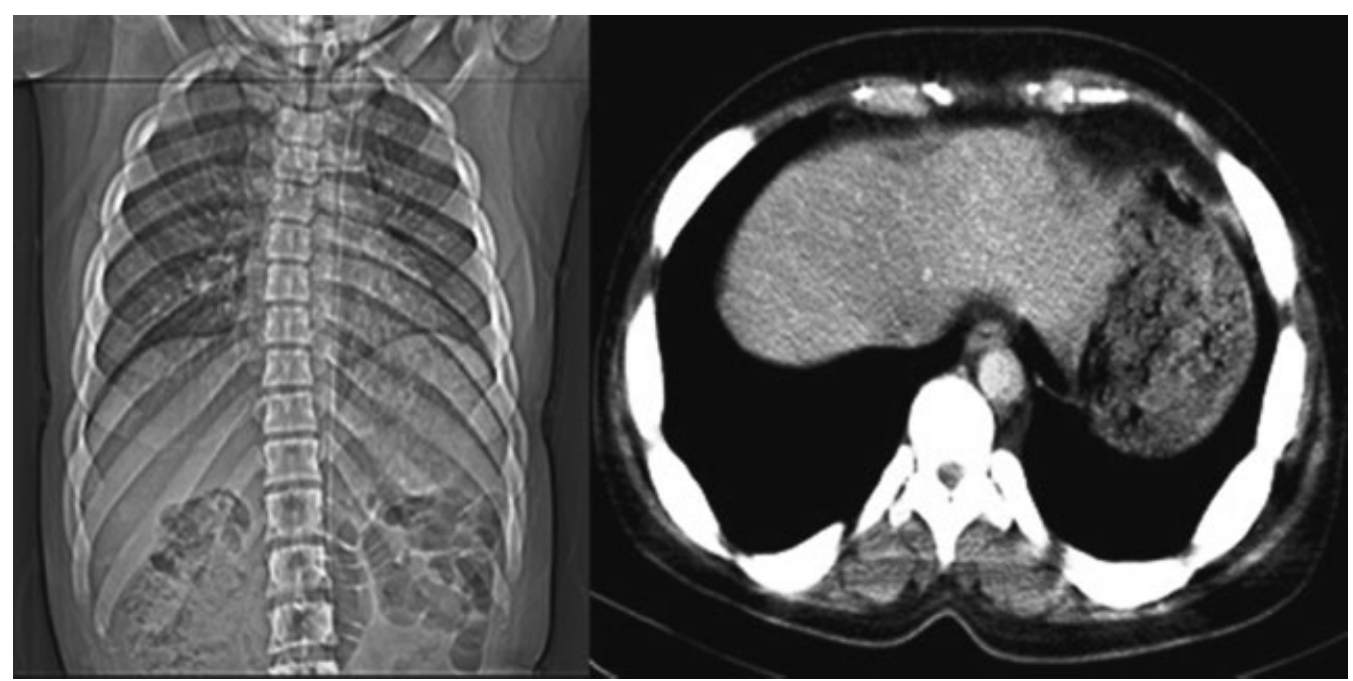

Fig. 2 On the CT scan of the abdominal cavity, spine and ribs are seen thickened and sclerotic.

and dysphagia, and also partial recovery in sensory and motor deficits. The clinical symptoms, such as headache, visual and auditory losses, and facial paralysis did not recover. MRI revealed a smaller syrinx cavity than the preoperative imaging (-Fig. $\mathbf{5}$ ).

\section{Discussion}

Craniodiaphyseal dysplasia, especially involving the skull and facial bones, is a sclerotic bone disorder. There are very few case reports published in the literature associated with this disease. The pathogenesis of this condition is not fully understood, because although a recessive mode of inheritance has been suggested for most of the sporadic cases, an autosomal dominant case has been reported as well. $^{12-15}$

Craniodiaphyseal dysplasia is characterized by thickening, distortion, and enlargement of the bones of the cranium and face, which are the leading causes of the multiple deformity. ${ }^{12,16}$ Diagnostic radiographic features consist of osteosclerosis and hyperostosis of the skull and facial bones. Moreover, many other skeletal and visceral abnormalities may occur, such as: situs inversus totalis, tubular structure of the long bones, and thickening of the ribs, pelvis, and vertebral column. ${ }^{12-14,17}$ Camurati-Engelmann disease (progressive diaphyseal dysplasia; an autosomal dominant disorder), Worth-type endosteal hyperostosis (an autosomal dominant osteosclerosis) and sclerosteosis (an autosomal recessive disorder) may present with similar clinical findings as CDD. ${ }^{18-20}$ However, CDD differs from these craniotubular disorders by the degree of involvement of the craniofacial and long-cylindrical bones. ${ }^{13,17,19}$ In the histopathological evaluation of CDD in the previous studies, fibrous tissue, inflammatory response, prominent osteoblasts and variable osteocytes were shown in the thickened trabecular bone. The trabeculae were in contact with osteoid seams, which 


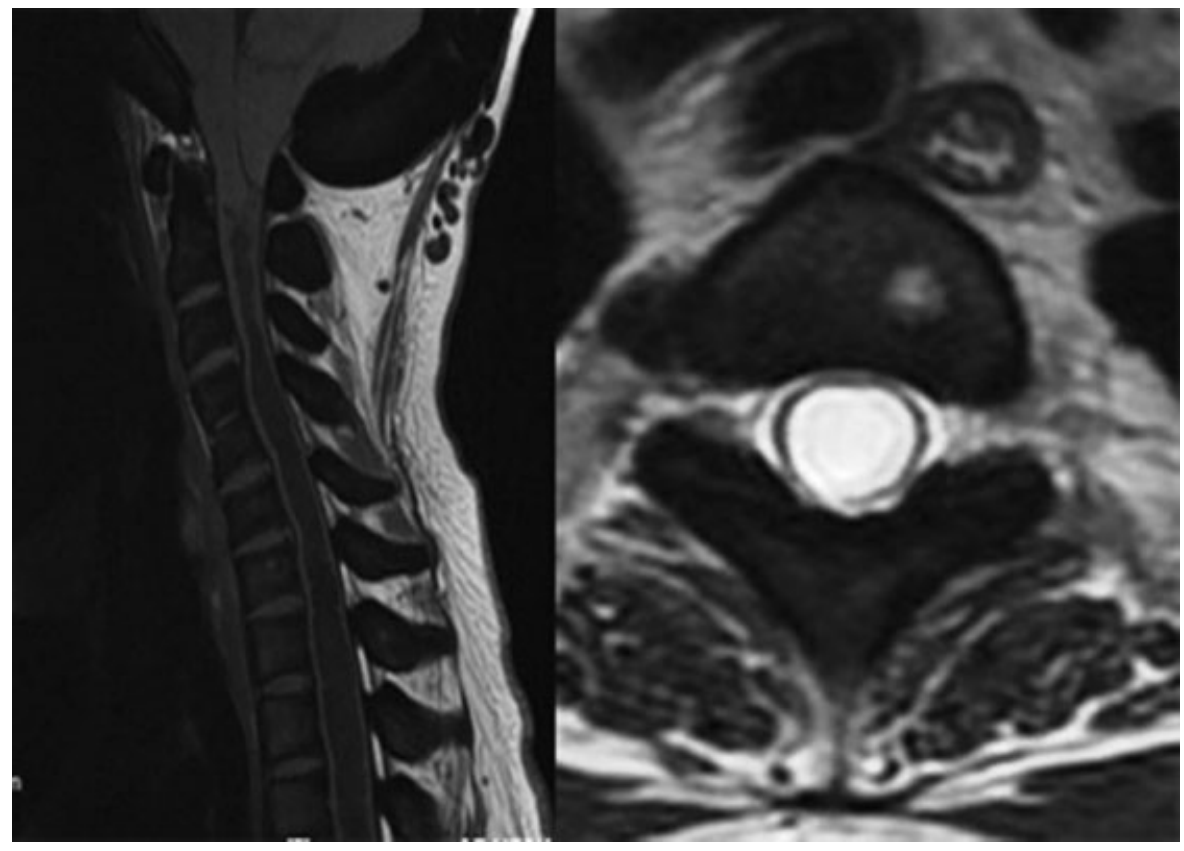

Fig. 3 On the MRI, displacement of the cerebellar tonsils below the foramen magnum and syringomyelia are seen.

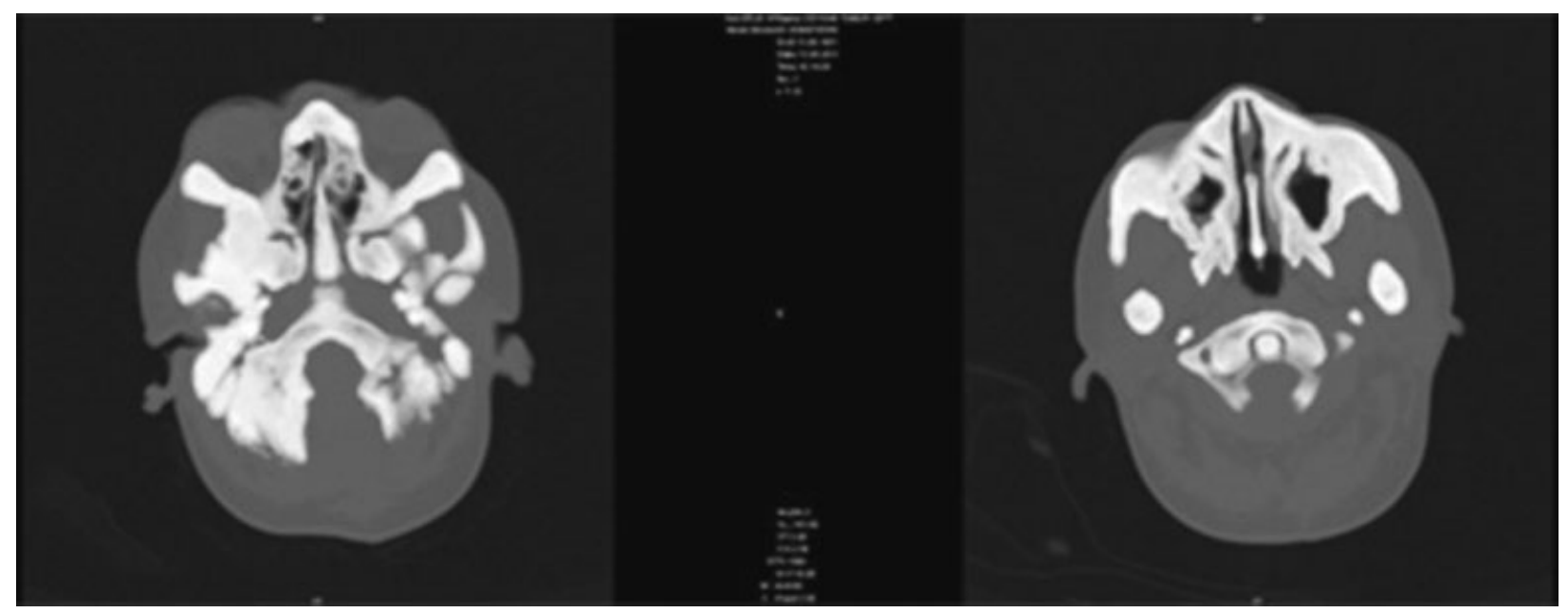

Fig. 4 Suboccipital craniectomy and C-1 laminectomy shown on cranial CT images.

contained osteoblasts and osteocytes; in addition, there was lack of calcification in the samples. ${ }^{21}$

Cranial foraminal stenosis and reduced volume of the cranial vault produces the neurological signs and symptoms of CDD. While cranial nerve compression (especially cranial nerves II, VII, and VIII) occurs as a result of cranial foraminal stenosis, the reduced volume of the cranial vault increases the intracranial pressure (ICP). Symptoms of CDD may include headaches, visual and auditory impairment, epiphora, recurrent dacryocystitis, respiratory difficulties, generalized weakness, balance problems, loss of sensation and mental retardation. In addition, growth and sexual maturation may be delayed, but most of the patients cannot survive after childhood. ${ }^{12,17,21,22}$ The patient also suffered hearing loss and bilateral peripheral facial paralysis due to the significant narrowing of the IAC, and visual loss due to the narrowing of the OF. In addition, there were phonation disturbances and difficulty in swallowing due to lower cranial nerve palsies.

Although the syndrome and its early complications are well described, the delayed complications in adults are not properly known. Furthermore, stenosis of the vertebral canal, small posterior fossa, CM-I and syringomyelia were described as the late complications of this rare syndrome in the literature. ${ }^{22-24}$ Mocco et al described two patients with CM-I. In these presentations, they showed that the ventriculoperitoneal shunt and PCF decompression surgeries weren't successful in treating the symptoms, and instead of these procedures, they suggested the method of multiple small craniotomies with the replacement of thinned bone 


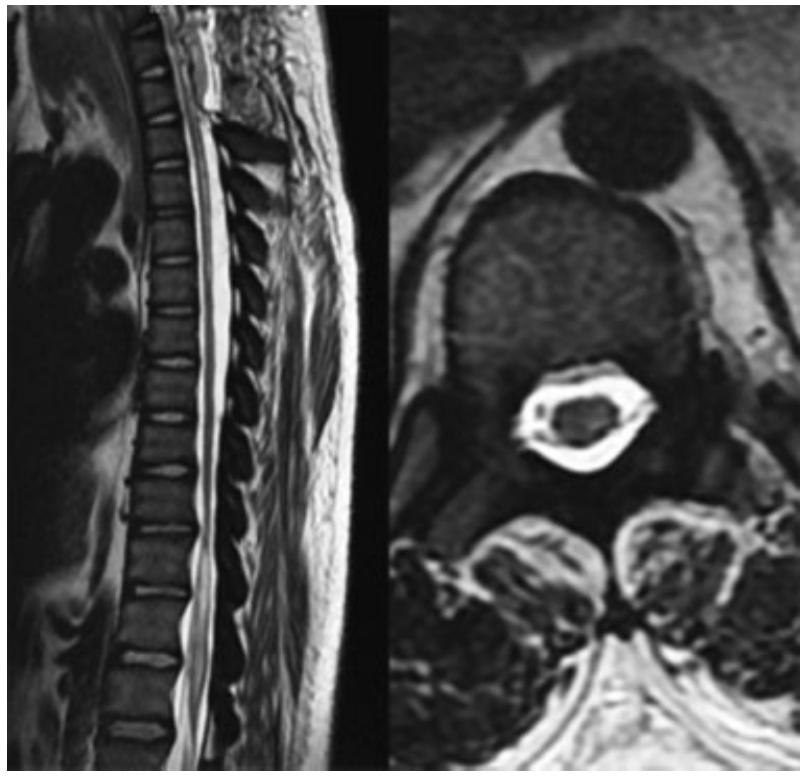

Fig. 5 The MRI images reveal the recovery of the syringomyelia.

flaps. ${ }^{25}$ Jacques J. et al reported a series of fourteen patients. In this series, they preferred PCF decompression as the first surgical option for six patients, but two of the patients died at the postoperative first day because of downward migration of the brain stem into the FM (postmortem examination confirmed signs of pressure necrosis in the lower medulla oblongata). According to the evaluation of the series, we assume that if supratentorial cranial decompression was the first procedure to be chosen, CM-I and its complications require another treatment modality at the end of the process (such as decompression of the PCF). ${ }^{19}$ On the other hand, L. Albert Jr et al claimed that PCF decompression might cause mortal results, and recommended the subtemporal decompression technique instead. ${ }^{22}$ However, it has been shown in previous studies that in patients with $\mathrm{CM}-\mathrm{I}$, decompression of the brain stem at the FM and maintaining the cerebrospinal fluid flow at the craniocervical junction is mandatory for the treatment. Additionally, in the presence of syringomyelia, syringosubarachnoid shunting may be necessary. ${ }^{8,9}$ Our patient had syringomyelia and CM-I, presenting with headache, lower cranial nerve involvement and cerebellar findings. In the first operation, the patient underwent PCF decompression at sitting position. In the second session, a syringosubarachnoid shunting was performed. In the postoperative clinical follow-up, the symptoms of lower cranial nerve palsy recovered, but the symptoms of the foraminal stenosis, such as visual and auditory losses and facial paralysis did not recover in any way. In the treatment of these patients with CDD, PCF decompression and syringosubarachnoid shunting is necessary, in spite of all the risks of these procedures. However, in addition to these procedures, different treatment strategies, such as foraminal and supratentorial cranial decompressive surgeries must be considered for the symptoms secondary to the increased ICP and the cranial nerve entrapment.
Treatment options are limited for CDD. Although decompressive cranioplasty may offer some relief of the symptoms, other special surgical treatment strategies, such as dacryocystorhinostomy may be mandatory. ${ }^{21,26}$ The conservative treatment modalities, such as medical therapy or low calcium diets and calcitonin therapy did not prevent the progression of the disease. ${ }^{27,28}$ We did not prefer the conservative treatment options because of the insufficient clinical evidence.

\section{Conclusions}

Chiari malformation type-I and syringomyelia frequently occurs in CDD and other similar rare pathologies as a result of hyperostosis of the cranial bones. In addition, cranial foraminal stenosis and reduced volume of the cranial vault are the leading causes of cranial nerve compression and increased ICP. For that reason, it is usually hard to choose the most appropriate treatment option. In this case report we suggest that for the patients with CM-I and syringomyelia with CDD, PCF decompression and syringosubarachnoid shunting could be the choice of treatment.

\section{References}

1 Atkinson JL, Weinshenker BG, Miller GM, Piepgras DG, Mokri B. Acquired Chiari I malformation secondary to spontaneous spinal cerebrospinal fluid leakage and chronic intracranial hypotension syndrome in seven cases. J Neurosurg 1998;88(2):237-242

2 Fenoy AJ, Menezes AH, Fenoy KA. Craniocervical junction fusions in patients with hindbrain herniation and syringohydromyelia. J Neurosurg Spine 2008;9(1):1-9

3 Loukas M, Shayota BJ, Oelhafen K, et al. Associated disorders of Chiari Type I malformations: a review. Neurosurg Focus 2011; 31(3):E3

4 Milhorat TH, Chou MW, Trinidad EM, et al. Chiari I malformation redefined: clinical and radiographic findings for 364 symptomatic patients. Neurosurgery 1999;44(5):1005-1017

5 Milhorat TH, Nishikawa M, Kula RW, Dlugacz YD. Mechanisms of cerebellar tonsil herniation in patients with Chiari malformations as guide to clinical management. Acta Neurochir (Wien) 2010; 152(7):1117-1127

6 Roohi F. Teaching NeuroImages: Acquired Chiari malformation with syringohydromyelia caused by posterior fossa. Neurology 2011;77(7):700, author reply 700

7 Wu FZ, Fu JH, Chen JY, Lai PH. Teaching NeuroImages: acquired Chiari malformation with syringohydromyelia caused by posterior fossa tumor. Neurology 2010;75(14):e59

8 Batzdorf U. Chiari I malformation with syringomyelia. Evaluation of surgical therapy by magnetic resonance imaging. J Neurosurg 1988;68(5):726-730

9 Erdogan E, Cansever T, Secer HI, et al. The evaluation of surgical treatment options in the Chiari Malformation Type I. Turk Neurosurg 2010;20(3):303-313

10 Hida K, Iwasaki Y, Koyanagi I, Sawamura Y, Abe H. Surgical indication and results of foramen magnum decompression versus syringosubarachnoid shunting for syringomyelia associated with Chiari I malformation. Neurosurgery 1995;37(4):673-678, discussion 678-679

11 Oldfield EH, Muraszko K, Shawker TH, Patronas NJ. Pathophysiology of syringomyelia associated with Chiari I malformation of the cerebellar tonsils. Implications for diagnosis and treatment. J Neurosurg 1994;80(1):3-15 
12 Brueton LA, Winter RM. Craniodiaphyseal dysplasia. J Med Genet 1990;27(11):701-706

13 Marden FA, Wippold FJ II. MR imaging features of craniodiaphyseal dysplasia. Pediatr Radiol 2004;34(2):167-170

14 Ozturk S, Zor F, Coskun U, Gul D, Duzgun S, Sengezer M. Situs inversus totalis with accompanying craniodiaphysial dysplasia: a new syndrome? J Craniofac Surg 2004;15(5):865-869

15 Schaefer B, Stein S, Oshman D, et al. Dominantly inherited craniodiaphyseal dysplasia: a new craniotubular dysplasia. Clin Genet 1986;30(5):381-391

16 Bieganski T, Baranska D, Miastkowska I, Kobielski A, GorskaChrzastek M, Kozlowski K. A boy with severe craniodiaphyseal dysplasia and apparently normal mother. Am J Med Genet A 2007; 143A(20):2435-2443

17 Vanhoenacker FM, De Beuckeleer LH, Van Hul W, et al. Sclerosing bone dysplasias: genetic and radioclinical features. Eur Radiol 2000;10(9):1423-1433

18 Curran AE, Pfeffle RC, Miller E. Autosomal dominant osteosclerosis: report of a kindred. Oral Surg Oral Med Oral Pathol Oral Radiol Endod 1999;87(5):600-604

19 du Plessis JJ. Sclerosteosis: neurosurgical experience with 14 cases. J Neurosurg 1993;78(3):388-392

20 Janssens K, Vanhoenacker F, Bonduelle M, et al. Camurati-Engelmann disease: review of the clinical, radiological, and molecular data of 24 families and implications for diagnosis and treatment. J Med Genet 2006;43(1):1-11
21 McHugh DA, Rose GE, Garner A. Nasolacrimal obstruction and facial bone histopathology in craniodiaphyseal dysplasia. Br J Ophthalmol 1994;78(6):501-503

22 Albert L Jr, Hirschfeld A. Acquired Chiari malformation secondary to hyperostosis of the skull: a case report and literature review. Surg Neurol 2009;72(2):157-161

23 Naique S, Laheri VJ. Stenosis of the cervical canal in craniodiaphyseal dysplasia. J Bone Joint Surg Br 2001;83(3):328-331

24 Simpson RK Jr, Fischer DK, Gall GK, Rose JE. Fatal cerebellar herniation secondary to Camurati-Englemann's disease. J Neurol Neurosurg Psychiatry 1988;51(10):1349-1352

25 Mocco J, Komotar RJ, Zacharia BE, Feldstein NA, Bruce JN. Aggressive cranial vault decompression for cranial hyperostosis: technical case report of two cases. Neurosurgery 2005;57(1, Suppl) E212, discussion E212

26 Sinow JD, Gruss JS, Roberts TS, Clarren SK, Graham CB, Mouradian W. Intracranial and extracranial reduction osteoplasty for craniodiaphyseal dysplasia. Cleft Palate Craniofac J 1996;33(4): 284-290

27 McKeating JB, Kershaw CR. Craniodiaphyseal dysplasia. Partial suppression of osteoblastic activity in the severe progressive form with calcitonin therapy. J R Nav Med Serv 1987;73(2): 81-93

28 Richards A, Brain C, Dillon MJ, Bailey CM. Craniometaphyseal and craniodiaphyseal dysplasia, head and neck manifestations and management. J Laryngol Otol 1996;110(4):328-338 